\title{
Oral hygiene frequency and presence of visible biofilm in the primary dentition
}

\author{
Freqüência de higiene bucal e presença de \\ biofilme visível na dentição decídua
}

\begin{abstract}
Ana Paula Pires dos Santos ${ }^{(a)}$ Mariana Canano Séllos ${ }^{(b)}$ Maria Eliza Barbosa Ramos ${ }^{(c)}$ Vera Mendes Soviero(d)
\end{abstract}

(a) Master's degree in Pediatric Dentistry; (b)DDS; (c) Professor, Department of Diagnosis and Surgery; ${ }^{(d)}$ Professor, Department of Community and Preventive Dentistry - School of Dentistry, Rio de Janeiro State University.

\author{
Corresponding author: \\ Ana Paula Pires dos Santos \\ Av. Roberto Silveira, 187/201 \\ Centro - Petrópolis - RJ - Brazil \\ CEP: 25685-040 \\ E-mail:paulapires@globo.com
}

\begin{abstract}
The purpose of this study was to associate oral hygiene frequency and presence of visible biofilm in the primary dentition. The sample consisted of 90 children, aged up to 4 years old, outpatients of the University Hospital of the Rio de Janeiro State University. The examinations were carried out in a dental office by a single trained examiner who was aided by an assistant. The parents answered a structured questionnaire about oral hygiene methods and frequency. Two biofilm indices, one simplified (BF1) and the other conventional (BF2), were used. BF1 classifies biofilm as absent, thin or thick, in anterior and/or posterior teeth, and provides a score for the patient, whereas BF2 classifies biofilm as absent or present, provides scores for three surfaces of each tooth and the final score is the percentage of tooth surfaces with biofilm. More than half of the parents (51-56.7\%) reported they cleaned their child's teeth at least twice a day, while $7(7.8 \%)$ had never cleaned their child's teeth. BF1 revealed that $12.2 \%$ (11) of the children had no visible biofilm, $37.8 \%$ (34) had thin biofilm in anterior and/or posterior teeth, $27.8 \%(25)$ had thick biofilm in anterior or posterior teeth and $22.2 \%(20)$ had thick biofilm in both anterior and posterior teeth. BF2 revealed a mean value of $21.8 \%$ (s.d. 16.5). No statistically significant correlations were found between oral hygiene frequency and the two biofilm indices $(p>0.05)$, indicating that oral hygiene frequency was not associated to oral hygiene quality in the evaluated sample.
\end{abstract}

Descriptors: Oral hygiene; Dental plaque index; Dentition, primary.

Resumo: O objetivo deste estudo foi associar freqüência de higiene bucal e presença de biofilme visível na dentição decídua. A amostra constou de 90 crianças com idade até 4 anos, cadastradas no Hospital Universitário da Universidade do Estado do Rio de Janeiro. Os exames foram realizados em consultório odontológico por um único examinador treinado, auxiliado por um anotador. Os pais responderam a um questionário estruturado sobre métodos e freqüência de higiene bucal. Foram utilizados dois índices de biofilme: um simplificado (BF1) e um convencional (BF2). O BF1 classifica o biofilme como ausente, fino ou espesso, em dentes anteriores e/ou posteriores, gerando um escore para o paciente, enquanto o BF2 classifica o biofilme como ausente ou presente, fornece escores a três superfícies de cada dente e o escore final corresponde ao percentual de superfícies com biofilme. Mais da metade dos pais $(51-56,7 \%)$ relataram limpar os dentes dos filhos pelo menos duas vezes ao dia ao passo que $7(7,8 \%)$ nunca tinham limpado os dentes dos filhos. O BF1 demonstrou que $12,2 \%$ (11) das crianças não apresentavam biofilme visível, $37,8 \%$ (34) apresentavam biofilme fino em dentes anteriores e/ou posteriores, $27,8 \%$ (25), biofilme espesso em dentes anteriores ou posteriores, e 22,2\% (20), biofilme espesso em dentes anteriores e posteriores. O BF2 revelou uma média de $21,8 \%$ (d.p. 16,5). Não foram encontradas correlações estatisticamente significativas entre a freqüência de higiene bucal e os índices de biofilme ( $\mathrm{p}>0,05)$, demonstrando que a freqüência de higiene bucal não esteve associada à qualidade da mesma na amostra estudada.

Descritores: Higiene bucal; Índice de placa dentária; Dentição decídua.
Received for publication on Mar 16, 2006 Sent for alterations on Jun 13, 2006 Accepted for publication on Aug 28, 2006 


\section{Introduction}

Several studies have assessed the prevalence of early childhood caries (ECC) throughout the world. Milnes $^{13}$ (1996), in a comprehensive review, observed a prevalence rate from 1 to $12 \%$ in developed countries and prevalence as high as $70 \%$ in developing countries or within disadvantaged populations. In Brazil, a national survey with 12,117 children aged 18-36 months old demonstrated that $26.9 \%$ of them had at least one cavitated caries lesion. ${ }^{4}$ Brazilian studies that have also registered noncavitated lesions showed prevalence between 35.9 and $55.3 \% .^{3,11,20}$ Surveys including AfroAmerican and Hispanic immigrants in the USA also considering noncavitated lesions have found a prevalence of ECC of $20 \%$ and 59\%, respectively. ${ }^{15,16}$

ECC should be considered a multifactorial disease whose etiology involves biological, ${ }^{22}$ psychosocial and behavioral factors. ${ }^{17}$ Individuals from lower socioeconomic strata find it hard to obtain professional health care and to live in a healthy environment, resulting in the development of negative behaviors towards their oral health. ${ }^{17}$ Thus, social class can be regarded as a controversial factor in the analysis of oral hygiene habits, such as toothbrushing. ${ }^{21}$ Studies that evaluated oral health behaviors in infants and preschool children have found that 36 to $92 \%$ of them had their teeth cleaned at least once a day. ${ }^{6,9,12,19,20,25}$ Provided cleaning is sufficiently thorough and performed daily, toothbrushing is considered to be the most reliable means of controlling biofilm. ${ }^{10}$

Clinical trials have already demonstrated that biofilm accumulation without mechanical disturbance leads to the development of white spot lesions. ${ }^{24}$ Daily toothbrushing associated to fluoride dentifrice has been considered the main reason for the decrease of caries prevalence since the 70's. In spite of that, the studies fail to show, at the population level, a clear association between oral hygiene and caries, probably due to the poor quality of biofilm removal performed by the patients. ${ }^{14}$ The association between oral hygiene habits and ECC is also controversial as some studies have found association between these variables, ${ }^{7,19,23}$ while others have not. ${ }^{6,12,25}$ However, when there is a high quality of biofilm removal, toothbrushing can be considered efficient to control caries. ${ }^{14}$
Concerning the quality of oral hygiene in children with primary dentition, it has already been evaluated by means of different biofilm indices. ${ }^{2,3,9,11,20} \mathrm{On}$ the other hand, the association between frequency and quality of oral hygiene in young children has not been highlighted in the literature.

The aim of this study was to associate oral hygiene frequency with the presence of visible biofilm in infants and preschool children using a simplified visible biofilm index as well as a conventional one.

\section{Material and Methods Subjects and study design}

The sample of this cross-sectional study consisted of 90 selected healthy patients, of both sexes, aged up to 4 years old and outpatients of the Pediatric Ambulatory of the University Hospital, Rio de Janeiro State University. It was a convenience sample and, to be included in the study, children should present, at least, the eight primary incisors erupted. The examinations were not previously scheduled. Parents were invited to participate while they were waiting for an ordinary appointment with the pediatrician.

\section{Ethical aspects}

Participation in the study was voluntary and written consent forms were obtained from parents. The study was approved by the Ethical Committee of the Biomedical Center, Rio de Janeiro State University (967-CEP/HUPE).

\section{Parental interview}

Parents were questioned about oral hygiene practices including: 1) how often did they clean their child's teeth; 2) which product was used to clean their child's teeth, meaning that they should point out if they used toothbrush with or without fluoride dentifrice, gauze, cotton or other. Parents were not asked about any specific technique or method of toothbrushing. All of them received information on caries prevention.

\section{Biofilm evaluation}

All clinical assessments were carried out in a dental office by a single trained examiner who was aided by an assistant. The children sat either in the dental 
chair or in the parent's lap. Mouth mirrors, exploratory probes and gauze were used. A simplified and a conventional biofilm index, both already employed in previous studies, were used. The presence of biofilm was evaluated without a disclosing solution. The simplified index, ${ }^{18}$ called in this study BF1, gives a score to the patient according to the amount of visible biofilm accumulated (absent, thin or thick) in anterior and/or posterior teeth, whereas the conventional index, ${ }^{1}$ called in this study BF2, evaluates the presence of visible biofilm in the mesial, buccal and lingual surfaces of all teeth. The BF $1^{18}$ was chosen to be used in this study because it is simple and easy to apply, which is an advantage when dealing with young children. However, as it was not used in such young children before, it was decided that a conventional index be used as well. The index proposed by Ainamo, Bay ${ }^{1}$ (1975) (BF2) was selected as previous studies in the primary dentition have already assessed biofilm based on its criteria. ${ }^{2,26}$

The index proposed by Ribeiro et al. ${ }^{18}$ (2002) (BF1) was modified by uniting some scores. Originally, the patient could be assigned a score ranging from 0 to 5 . In the modified index, the scale ranges from 0 to 3 , according to Chart 1 .

Patients were assigned score 0 when no visible biofilm was present, even after the teeth were dried with gauze. Score 1 was given when there was thin biofilm in anterior and/or posterior teeth (visible biofilm that could be seen only after careful drying with gauze). When only one region, anterior or posterior, presented thick biofilm, the patient was assigned score 2 . Finally, when there was thick biofilm in both anterior and posterior teeth (visible biofilm that could be seen without drying), the patient was assigned score 3 .

Chart 1 - Visible dental biofilm index* (BF1).

\begin{tabular}{c|l}
\hline 0 & Absence of visible biofilm. \\
\hline 1 & $\begin{array}{l}\text { Thin biofilm, easily removed, on anterior and/or posterior } \\
\text { teeth, visible only after drying with gauze. }\end{array}$ \\
\hline 2 & $\begin{array}{l}\text { Thick biofilm, firmly adhered, on anterior or posterior teeth, } \\
\text { visible without drying, associated or not to thin biofilm on } \\
\text { other teeth. }\end{array}$ \\
\hline 3 & $\begin{array}{l}\text { Thick biofilm, firmly adhered, on anterior and posterior teeth, } \\
\text { visible without drying. }\end{array}$ \\
\hline
\end{tabular}

*The original index was proposed by Ribeiro et al. ${ }^{18}$ (2002).
Concerning the index proposed by Ainamo, Bay ${ }^{1}$ (1975) (BF2), the scores 0, for absent biofilm, and 1, for present biofilm, were recorded for mesial, buccal and lingual surfaces of each tooth in a specific form. The percentage of tooth surfaces with visible biofilm was calculated.

\section{Statistical analysis}

The data were processed by means of the SPSS software, release 8.0 for Windows (SPSS Inc., Chicago, IL, USA) for descriptive analyses of oral hygiene frequency, oral hygiene method and biofilm indices. Spearman's correlation test was used to determine the association between oral hygiene frequency and the biofilm indices. The level of statistical significance was set at $5 \%$.

\section{Results}

More than half of the parents (51-56.7\%) reported they cleaned their child's teeth at least twice a day. Twenty-one $(23.3 \%)$ used to clean their child's teeth once a day, 11 (12.2\%), occasionally, and $7(7.8 \%)$ reported that their child's teeth had never been cleaned (Table 1).

The use of toothbrush associated to fluoride dentifrice was the most common way of cleaning the child's teeth, which was reported by $70 \%$ (63) of the parents (Table 2).

According to BF1, $12.2 \%$ (11) of the children had no visible biofilm, $37.8 \%$ (34) had thin biofilm in anterior and/or posterior teeth, $27.8 \%$ (25) had thick biofilm in anterior or posterior teeth and $22.2 \%(20)$ had thick biofilm in both anterior and posterior teeth (Table 3).

Table 4 shows that the percentage of BF2 ranged from 0 to $83.3 \%$, with a mean of $21.8 \%$ (s.d. 16.5 ).

No significant correlations $(\mathrm{p}>0.05)$ could be found between oral hygiene frequency and presence of visible biofilm expressed by both indices (Table 5).

Among the $51(56.7 \%)$ children who had their teeth cleaned at least twice a day, $27(52.9 \%)$ had scores 0 or 1 , and $24(47.1 \%)$ had scores 2 or 3 for $\mathrm{BF} 1$. Regarding BF2, despite the decrease from $30.9 \%$ among those whose teeth were never cleaned to $19.8 \%$ among those whose teeth were cleaned 
twice a day or more, this difference was not statistically significant.

\section{Discussion}

The presence of caries in infants and preschool children has been carefully studied and several risk factors have already been evaluated in order to determine their association with caries occurrence. When it comes to oral hygiene, most of the studies analyze it by means of interviews or questionnaires that ask parents about oral hygiene habits, such as the

Table 1 - Oral hygiene frequency reported by parents ( $\mathrm{n}=90)$.

\begin{tabular}{l|c|c}
\hline & $\mathrm{n}$ & $\%$ \\
\hline Never & 7 & 7.8 \\
\hline Occasionally & 11 & 12.2 \\
\hline Once a day & 21 & 23.3 \\
\hline Twice a day or more & 51 & 56.7 \\
\hline Total & 90 & 100.0 \\
\hline
\end{tabular}

Table 2 - Products used by parents to clean their child's teeth $(\mathrm{n}=90)$.

\begin{tabular}{l|r|r}
\hline & $n$ & $\%$ \\
\hline Toothbrush + fluoride dentifrice & 63 & 70.0 \\
\hline Toothbrush + nonfluoride dentifrice & 1 & 1.1 \\
\hline Toothbrush without dentifrice & 7 & 7.8 \\
\hline Gauze or cotton + water & 9 & 10.0 \\
\hline Other & 3 & 3.3 \\
\hline Do not clean their child's teeth & 7 & 7.8 \\
\hline Total & 90 & 100 \\
\hline
\end{tabular}

method and frequency of tooth cleaning. . $^{5-7,12,19,23,25}$ Some of these studies concluded that there was either no association or a weak association between oral hygiene and caries. ${ }^{5,6,12,25}$ However, Wendt et al. ${ }^{26}$ (1994) observed that if the habit of daily toothbrushing is adopted at as early as one year old, it is more likely that children will be caries free by the age of three.

The role of dental biofilm accumulation in caries initiation, progression and control is well established, ${ }^{24}$ which demonstrates that the sole evaluation of oral hygiene habits may be of limited value. Moreover, the report of toothbrushing habits is subject to response bias ${ }^{17}$ and gives no indication of the effectiveness of biofilm removal. ${ }^{21}$

In the present study, 11 (12.2\%) parents reported

Table 3 - Distribution of the sample according to the scores of the simplified visible biofilm index - BFl $(n=90)$.

\begin{tabular}{c|c|c}
\hline BFI & $n$ & $\%$ \\
\hline 0 & 11 & 12.2 \\
\hline 1 & 34 & 37.8 \\
\hline 2 & 25 & 27.8 \\
\hline 3 & 20 & 22.2 \\
\hline Total & 90 & 100.0 \\
\hline
\end{tabular}

Note: for the scores definition, see Chart 1.

Table 4 - Mean score, standard deviation and range for BF2, which was expressed as a percentage of tooth surfaces with visible biofilm $(\mathrm{n}=90)$.

\begin{tabular}{c|c|c|c|c|c}
\hline \multirow{2}{*}{ BF2 } & mean $\%$ & s.d. & $\min \%$ & $\max \%$ & $\mathrm{n}$ \\
\cline { 2 - 6 } & 21.8 & 16.5 & 0 & 83.3 & 90 \\
\hline
\end{tabular}

Table 5 - Correlation between oral hygiene frequency and the visible biofilm indices using Spearman's correlation test $(n=90)$.

\begin{tabular}{|c|c|c|c|c|c|c|c|c|c|c|c|}
\hline \multirow{3}{*}{ Oral hygiene frequency } & \multicolumn{8}{|c|}{$\mathrm{BF} 1$} & \multicolumn{3}{|c|}{ BF2 } \\
\hline & \multicolumn{2}{|c|}{0} & \multicolumn{2}{|c|}{1} & \multicolumn{2}{|c|}{2} & \multicolumn{2}{|c|}{3} & \multirow{2}{*}{$\mathrm{n}$} & \multirow{2}{*}{$\begin{array}{c}\text { Mean } \\
\%\end{array}$} & \multirow{2}{*}{ s.d. } \\
\hline & $\mathrm{n}$ & $\%$ & $\mathrm{n}$ & $\%$ & $\mathrm{n}$ & $\%$ & $\mathrm{n}$ & $\%$ & & & \\
\hline Never & 0 & 0 & 3 & 42.9 & 3 & 42.9 & 1 & 14.2 & 7 & 30.9 & 18.5 \\
\hline Occasionally & 1 & 9.1 & 5 & 45.4 & 2 & 18.2 & 3 & 27.3 & 11 & 25.3 & 20.5 \\
\hline Once a day & 3 & 14.3 & 6 & 28.6 & 7 & 33.3 & 5 & 23.8 & 21 & 21.9 & 19.4 \\
\hline Twice a day or more & 7 & 13.7 & 20 & 39.2 & 13 & 25.5 & 11 & 21.6 & 51 & 19.8 & 13.8 \\
\hline p value & & & & $=-0.6$ & $=0.5$ & & & & $r_{s}$ & $.12 / p=$ & .25 \\
\hline
\end{tabular}


they cleaned their child's teeth occasionally and 72 $(80.0 \%)$, at least once a day (Table 1$)$. This frequency is in accordance with that found by Dini et al. ${ }^{6}$ (2000), who observed that $85.3 \%$ of the 245 Brazilian children aged 3 to 4 years old had their teeth brushed at least once a day. The frequency of oral hygiene in the present study can be considered high when compared to that of another Brazilian study, which found that just $36 \%$ of the sample aged 12 to 36 months had their teeth cleaned. ${ }^{19}$ The percentage of oral hygiene frequency tends to be lower when children younger than 12 months old are included in the samples. In Saipan (USA), among 3,750 children aged 6 to 36 months, $54 \%$ used to have their teeth cleaned once or twice a day. ${ }^{12}$ In another Brazilian study, daily oral cleaning was observed in $76.3 \%$ of 80 children under 36 months old. ${ }^{20}$ In Thailand, in a group of 387 dentate children aged 6 to 19 months, $64.8 \%$ of the parents reported to have the habit of cleaning their child's teeth. ${ }^{25}$

Actually, more attention should be directed at assessing not only the oral hygiene habits and frequency of toothbrushing but also the quality of oral hygiene. Few studies comprising young children have assessed oral hygiene quality, ${ }^{2,3,9,11,20}$ though many biofilm and gingival indices have already been devised as appropriate methods to evaluate oral hygiene quality.

The simplified visible biofilm index (BF1) used in the present study has been employed in its original version in a sample of children with primary and mixed dentition. ${ }^{18}$ In the present study, however, the index was modified to reduce the number of scores and facilitate its application in very young children. The other index, the visible plaque index, ${ }^{1}$ cited in this study as BF2, was used as it has been employed in a large number of studies since its first description.

The sole evaluation of biofilm may not be enough as patients tend to improve dental cleanliness when they know they will be examined by a dentist. Therefore, gingival assessment is recommended. ${ }^{8}$ In this study, however, the parents were not aware that their child would be seen by a dentist. Children were scheduled for a medical appointment and, once in the waiting room, were invited to undergo a dental examination. Although the association between biofilm and gingival indices has not been evaluated in this study, it would be interesting to combine biofilm and gingival assessment in a further research involving this age group.

The results of this study showed that the children who had their teeth cleaned twice or more times a day were not necessarily the same that had thin biofilm or no visible biofilm (Table 5). According to BF1, about half of the children who had their teeth cleaned at least twice a day presented thick biofilm. Regarding BF2, despite the decrease in the percentage of dental surfaces with biofilm among those whose teeth were cleaned twice a day or more, this difference was not statistically significant. The lack of association between the reported toothbrushing frequency and the presence of visible biofilm is in agreement with Habibian et al. ${ }^{9}$ (2001), whose results also failed to show this association in infants, indicating that a more frequent habit of toothbrushing may not reflect better oral hygiene quality. This fact places emphasis on the need for more specific guidance regarding dental cleaning. Although parents brushed their child's teeth, they did not manage to disturb biofilm properly, probably because they have not been advised how to do that. Generally, when parents brush their child's teeth they are more worried about removing pieces of food than disorganizing biofilm at the stagnation areas. Suitable training in toothbrushing should be provided so that parents become able to recognize visible biofilm, therefore increasing the probability of performing satisfactory biofilm control.

\section{Conclusion}

No significant correlations were found between oral hygiene frequency and presence of visible biofilm expressed by the simplified and the conventional indices, which means that oral hygiene frequency was not associated to oral hygiene quality in the evaluated sample. The results indicate that a more specific guidance to parents regarding dental cleaning is needed. More important than tell parents to brush their children's teeth twice or three times a day is to instruct them how to disorganize dental biofilm properly. In addition, the results call the attention for the fact that further studies concerning 
the relation between the ocurrence of dental caries and oral hygiene habits should consider not only the frequency of toothbrushing but also the quality of tooth cleanliness by assessing a biofilm index.

\section{References}

1. Ainamo J, Bay I. Problems and proposals for recording gingivitis and plaque. Int Dent J. 1975;25(4):229-35.

2. Alaluusua S, Malmivirta R. Early plaque accumulation - a sign for caries risk in young children. Community Dent Oral Epidemiol. 1994;22(5):273-6.

3. Barros SG, Castro Alves A, Pugliese LS, Reis SRA. Contribuição ao estudo da cárie dentária em crianças de 0-30 meses. Pesqui Odontol Bras. 2001;15(3):215-22.

4. Brasil. Projeto SB Brasil 2003: condições de saúde bucal da população brasileira 2002-2003. Resultados principais. Brasília: Ministério da Saúde. Coordenação Nacional de Saúde Bucal; 2004.

5. Cariño KMG, Shinada K, Kawaguchi Y. Early childhood caries in northern Philippines. Community Dent Oral Epidemiol. 2003;31(2):81-9.

6. Dini EL, Holt RD, Bedi R. Caries and its association with infant feeding and oral health-related behaviours in 3-4-yearold Brazilian children. Community Dent Oral Epidemiol. 2000;28(4):241-8.

7. Douglass JM, Tinanoff N, Tang JMW, Altman DS. Dental caries patterns and oral health behaviors in Arizona infants and toddlers. Community Dent Oral Epidemiol. 2001;29(1):1422.

8. Ekstrand KR, Bruun G, Bruun M. Plaque and gingival status as indicators for caries progression on approximal surfaces. Caries Res. 1998;32(1):41-5.

9. Habibian M, Roberts G, Lawson M, Stevenson R, Harris S. Dietary habits and dental health over the first 18 months of life. Community Dent Oral Epidemiol. 2001;29(4):239-46.

10. Löe H. Oral hygiene in the prevention of caries and periodontal disease. Int Dent J. 2000;50(3):129-39.

11. Mattos-Graner RO, Zelante F, Line RCSR, Mayer MPA. Association between caries prevalence and clinical, microbiological and dietary variables in 1.0 to 2.5 -year-old Brazilian children. Caries Res. 1998;32(5):319-23.

12. Milgrom O, Riedy CA, Weinstein P, Tanner ACR, Manibusan L, Bruss J. Dental caries and its relationship to bacterial infection, hypoplasia, diet and oral hygiene in 6- to 36-month-old children. Community Dent Oral Epidemiol. 2000;28(4):295-306.

13. Milnes AR. Description and epidemiology of nursing caries. J Public Health Dent. 1996;56(1):38-50.

\section{Acknowledgments}

The authors would like to thank Professor Ronir Raggio Luiz for his valuable contribution to the statistical analysis.

14. Nyvad B. The role of oral hygiene. In: Fejerskov O, Kidd E. Dental caries - The disease and its clinical management. Copenhagen: Blackwell Munksgaard; 2003. p. 171-7.

15. Quiñonez RB, Keels MA, Vann WF Jr, McIver FT, Heller K, Whitt JK. Early childhood caries: analysis of psychosocial and biological factors in a high-risk population. Caries Res. 2001;35(5):376-83.

16. Ramos-Gomez FJ, Weintraub JA, Gansky SA, Hoover CI, Featherstone JDB. Bacterial, behavioral and environmental factors associated with early childhood caries. J Clin Pediatr Dent. 2002;26(2):165-73.

17. Reisine S, Douglass JM. Psychosocial and behavioral issues in early childhood caries. Community Dent Oral Epidemiol. 1998;26 Suppl 1:32-44.

18. Ribeiro AA, Portela M, Souza, IP. Relation between biofilm, caries activity and gingivitis in $\mathrm{HIV}^{+}$children. Pesqui Odontol Bras. 2002;16(2):144-50.

19. Rosenblatt A, Zarzar P. The prevalence of early childhood caries in 12- to 36-month-old children in Recife, Brazil. ASDC J Dent Child. 2002;69(3):319-24.

20. Santos APP, Soviero VM. Caries prevalence and risk factors among children aged 0 to 36 months. Pesqui Odontol Bras. 2002;16(3):203-8.

21. Sayegh A, Dini EL, Holt RD, Bedi R. Oral health, sociodemographic factors, dietary and oral hygiene practices in Jordanian children. J Dent. 2005;33(5):379-88.

22. Seow WK. Biological mechanisms of early childhood caries. Community Dent Oral Epidemiol. 1998;26 Suppl 1:8-27.

23. Stecksén-Blicks C, Sunnegårdh K, Borssén E. Caries experience and background factors in 4-year-old children: time trends 1967-2002. Caries Res. 2004;38(2):149-55.

24. Thylstrup A, Bruun C, Holmen L. In vivo caries models mechanisms for caries initiation and arrestment. Adv Dent Res. 1994;8(2):144-57.

25. Vachirarojpisan T, Shinada K, Kawaguchi Y, Laungwechakan P, Somkote T, Detsomboonrat P. Early childhood caries in children aged 6-19 months. Community Dent Oral Epidemiol. 2004;32(2):133-42.

26. Wendt LK, Hallonsten AL, Koch G, Birkhed D. Oral hygiene in relation to caries development and immigrant status in infants and toddlers. Scand J Dent Res. 1994;102(5):269-73. 